\title{
A atuação do repórter na cobertura televisiva de tragédias: o olhar do jornalista como testemunha do fato que enuncia
}

\author{
ILUSKa Coutinho \\ UFJF - Brasil - iluskac@globo.com \\ Jornalista, doutora em Comunicação Social (Umesp) e mestre em Comunicação e Cultura (UnB). Professora do \\ Departamento de Jornalismo e do Mestrado da Faculdade de Comunicação da UFJF
}

JHONATAN MATA

UFJF - Brasil - jhonatanmata@yahoo.com.br Jornalista e mestre em Comunicação (UFJF), é funcionário da Faculdade de Comunicação da UFJF e realiza pesquisas sobre telejornalismo. Integrante do grupo de pesquisa Jornalismo, Imagem e Representação

\section{Resumo}

O trabalho analisa as especificidades dos papéis desempenhados pelos telejornalistas na cobertura televisiva de catástrofes climáticas. Consideramos, tendo como recorte empírico dois casos particulares, que o repórter assume, com frequência, parte da proposta de humanização do relato, ao se colocar como testemunha das histórias. Com isso, o encontro entre emissora e público, ou sua simulação, passa a ser mediado também pelas maneiras com que os jornalistas se colocam em cena. Seja numa postura de defesa do cidadão, atuando como o fiscal, ou ao enunciar verbalmente fatos e emoções tal como o arauto, tais personagens/jornalistas estão presentes nas "histórias" cobertas por duas jornalistas de referência no telejornalismo brasileiro, e veiculadas no Fantástico e no Jornal Nacional. As pautas tomadas como objeto de reflexão centraram-se na cobertura de duas tragédias climáticas ocorridas no Rio de Janeiro: os deslizamentos nos municípios serranos do estado, em janeiro de 2011 e no Morro do Bumba, em Niterói, em abril de 2010. Os depoimentos das jornalistas Sônia Bridi e Fátima Bernardes serviram de recorte para análise do papel do repórter e seu lugar de referência na cobertura de tragédias. 
Estudos em Jornalismo e Mídia - Vol. $10 \mathrm{~N}^{\circ} 2$ - Julho a Dezembro de 2013

ISSNe 1984-6924

DOI: http://dx.doi.org/I0.5007/I984-6924.2013v10n2p379

Palavras-chave

Cobertura midiática, dramaturgia do telejornalismo, jornalista, arauto, fiscal

\begin{abstract}
The paper analyzes the specifics of the roles played by TV journalists in television coverage of climate catastrophes. We believe, with the empirical cut of two particular cases, the reporter takes often part of the proposed humanization of the story, standing as a witness to the stories. With that, the meeting between broadcaster and audience, or its simulation, also happens to be mediated by the ways in which journalists put themselves in the scene. Having a citizen's defense posture, acting as the fiscal or verbally by stating facts and emotions as the herald, such characters / journalists are present in "stories" covered by two reference journalists in Brazilian television journalism, and conveyed at the Fantástico and the Jornal Nacional. The guidelines adopted as the object of reflection focused on climate cover two tragedies that occurred in Rio de Janeiro: Slips at municipalities "serranos" in the state in January 2011 and at the Morro do Bumba, Niterói, in April 2010. The testimonies of journalists Sonia Bridi and Fatima Bernardes served as a cutout for analyzing the role of the reporter and his place of reference in covering tragedies.
\end{abstract}

\title{
Keywords
}

Media coverage, TV journalism dramaturgy, journalist, herald, fiscal

Artigo recebido em 31/08/2012

Aprovado em 17/05/2013 


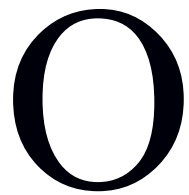
fato de ser um país "abençoado por Deus e bonito por natureza"' não impede a ocorrência de tragédias e desastres climáticos, alguns deles em virtude de ações do próprio homem contra o meio ambiente. Fugindo, de antemão de qualquer discurso ambientalista, que não é foco de nossa análise, é fato que os anos de 2010 e 2011 figuraram com certa representatividade em relação à quantidade de catástrofes climáticas de grande porte no Brasil. Os deslizamentos em Angra dos Reis, as chuvas no Rio de Janeiro, em São Paulo e em cidades do nordeste, em 2010 e os deslizamentos ocorridos nas cidades serranas do Rio de Janeiro, em 2011 (considerado o maior desastre "natural" do país) encabeçam a lista de tragédias que assolaram a população, com mais de 900 mortos no último caso, além de mais de 200 desaparecidos e milhares de desabrigados e desalojados.

Parte do (meio) ambiente, o jornalista de televisão é responsável por acompanhar esse tipo de situação, muitas vezes traumática, e narrar os fatos, descrevendo os cenários e seus personagens para o público. A cobertura de tragédias no telejornalismo tem uma série de características e aspectos merecedores de atenção, seja com relação a questões de ordem técnica, operacional, ética e mesmo estética. No âmbito desse texto, propomos uma reflexão sobre a atuação dos repórteres de televisão como parte desses cenários trágicos, termo cujo sentido será desdobrado posteriormente.

Antes é necessário atentar para as características particulares desse tipo de cobertura, sempre tendo como foco preferencial de atenção o chamado lugar de fala do jornalista televisivo, e/ou o que se espera desse tipo de profissional em situações de coberturas de acontecimentos de grande impacto, também emocional.

Definindo tragédia como uma forma de desastre em escala menor, Ted White alerta para a dificuldade desse tipo de cobertura para os repórteres:

1 Trecho da canção "País Tropical”, de Jorge Benjor. 
(...)costumam ser mais difíceis de cobrir que desastres em grande escala porque se tornam mais pessoais. (...) Repórteres podem chorar, e algumas vezes o fazem - sozinhos. Eles devem, no entanto, cobrir tais matérias da forma menos emocional possível e partir para a próxima. (WHITE, 2008, p.209).

Esse tipo de recomendação, parte de uma cartilha profissional que deveria ser internalizada, constituir-se como parte do ethos do (tele)jornalista, é com frequência objeto de discussões capazes de envolver da emissora aos telespectadores. Não são raras as críticas, presentes inclusive em espaços opinativos em outras mídias, tais como portais e blogs, acerca da atuação dos repórteres em matérias que tem como pauta desastres e tragédias naturais. Desde a falta de sensibilidade e/ou excessiva redundância dos profissionais ao formularem perguntas às vítimas, por exemplo, aos possíveis excessos cometidos na edição, acusada de assumir um tom caracterizado como sensacionalista, esse tipo de cobertura televisiva parece ser capaz de mobilizar profissionais, audiência e críticos. Ao menos em situações de crise, poderíamos ter potencializada a ocorrência de um debate acerca dos fazeres (tele)jornalísticos, embora na maioria das vezes as discussões sejam encerradas com um diagnóstico ou sentença de condenação a repórteres, pela inabilidade, e a emissoras, pela ausência de limites na busca pela audiência.

Em geral esse tipo de análise acerca da cobertura televisiva é feita a partir de um olhar estrangeiro, isso é, por atores sociais que não partilham das rotinas profissionais de repórteres, cinegrafistas e editores de telejornais. Reunidos sob a condição de telespectadores, estes formulam críticas a matérias sobre tragédias e desastres, e buscam identificar traços de identidade ou alteridade entre a atuação dos repórteres televisivos e o que poderia ser caracterizado como modelo normativo do jornalismo, a partir da perspectiva do público. Nesse caso o repórter ocuparia o lugar de um outro, distinto do cidadão comum; narrador dos dramas sociais ele não deveria, de acordo com as expectativas para ele construídas pelo público e mesmo pelos manuais, envolver-se com 
aspectos emocionais do fato ou situação a ser noticiada. Esse (tele)jornalista, quase arquetípico, posiciona-se confortavelmente em um ideal de jornalismo como construção eminentemente racional, e objetiva.

Em uma obra que conta com depoimentos de profissionais como Gilberto Dimenstein, Marília Gabriela, Boris Casoy, Joelmir Beting, Otávio Frias Filho e Caio Tulio Costa, já em 1991 o autor Geraldinho Vieira lançava dúvida sobre os "superpoderes" dos jornalistas, que padeceriam do "complexo de Clark Kent", referência ao personagem Super-Homem, da DC Comics. Na prática profissional, a exigência por uma postura neutra ou menos emotiva durante a cobertura de tragédias pode gerar grande estresse psicológico segundo o American Journalism Review (AJR). Em documento no qual são descritos traumas e dilemas dos jornalistas que teriam contato com cenas e situações de horror,

a jornalista do AJR observa que, embora tais coberturas possam criar intenso estresse psicológico, o script padrão em uma redação pede estoicismo. Admitir o abalo emocional, segundo ela, colide com a conduta equilibrada e não-passional da qual a profissão tanto se orgulha (WHITE, 2008, p. 219).

Mas, embora a cobertura de temáticas violentas e de outras emergências, das ocorrências factuais no jornalismo eletrônico com frequência recaia sobre jornalistas novatos, segundo Ted White os desastres naturais que se impõem como grandes tragédias seriam uma boa oportunidade para que as emissoras televisivas mostrassem seus maiores talentos. $\mathrm{O}$ autor faz referência a uma reportagem assinada por Jacques Steinberg no The New York Times segundo a qual os executivos de TV e as emissoras estariam atentos ao fato de que, à despeito da queda de audiência dos últimos anos, os tempos de crise seriam também chances de reencontro com o público, "uma chance rara de tentar reconquistar o interesse do público" (WHITE, 2008, p. 208).

Os grandes desastres em geral demandam uma cobertura continuada das emissoras de televisão, e por isso também envolvem uma logística diferenciada de 
produção. Além dos plantões com revezamento de repórteres e transmissões ao vivo, também as estrelas das emissoras integram a equipe em coberturas televisivas que adquirem um caráter de excepcionalidade, e podem render prêmios, ou ao menos indicações. De acordo com William Bonner "entre os anos de 2002 e 2008 o Jornal Nacional foi quatro vezes finalista do Emmy International. E em todas essas oportunidades foram edições atípicas que nos levaram a Nova Iorque para a cerimônia de premiação" (2009, p. 155). Também foi uma cobertura televisiva especial, ainda que nesse caso planejada, a cobertura da invasão do Morro do Alemão, que rendeu em 2011 ao noticiário da emissora o Emmy Awards na categoria notícia.

Mais de 20 repórteres da Rede Globo participaram da cobertura durante o cerco e a tomada da favela - a TV Globo transmitiu toda a operação ao vivo, com uma redação inteira a postos para levar ao ar as imagens que fizeram o Brasil parar em frente à TV. Fazem parte dessa cobertura as impressionantes imagens da fuga de centenas de traficantes armados feitas pelo Globocop, a descoberta de que traficantes usaram o esgoto para fugir e o espaço dado para que os moradores falassem da sensação de liberdade após a chegada dos policiais. (Globo.com, 2011).

Em coberturas especiais, ainda que em eventos não planejados, como desastres naturais, a emissora desloca seus repórteres especiais e, algumas vezes, modifica até mesmo o modelo padrão de enunciação de seus telejornais, que passam a ser apresentados, por exemplo, do local da tragédia. Esse caráter de excepcionalidade marca as duas coberturas tomadas como recorte empírico nessa reflexão. A primeira delas foi realizada em abril de 2010, nas chuvas que provocaram deslizamentos de terras e mortes em Niterói. Naquela ocasião, a edição do Jornal Nacional de 08 de abril foi apresentada direto do Morro do Bumba por Fátima Bernardes, enquanto William Bonner mantinhase na bancada do telejornal. O outro episódio foi a cobertura do que denominou-se na mídia televisiva como o maior desastre natural brasileiro, as chuvas de janeiro de 2011 na região serrana do estado do Rio de Janeiro. A cobertura da "chuva destruidora" exibida no Jornal Nacional e no Fantástico foi responsável pela sétima indicação do jornalismo da Rede Globo ao Emmy Awards, em 2012. 
Tendo como perspectiva a análise do lugar, diferenciado, do repórter nesse tipo de matéria televisiva, a reflexão toma como documento de investigação duas entrevistas concedidas por jornalistas televisivas implicadas na cobertura das tragédias do Morro do Bumba e da Região Serrana, Fátima Bernardes e Sônia Bridi, respectivamente. Disponível nas páginas do Jornal Nacional e do Fantástico na internet, esse material não foi veiculado na televisão, mas incorpora fragmentos das coberturas e desvela parte de seu processo de produção, com destaque para o jornalista e suas práticas e percepções. Nesse caso, por tratarem-se de jornalistas de referência na emissora, haveria uma maior fluidez quanto a fronteiras ou bordas, sendo menores as interdições quanto à explicitação de aspectos emocionais, antes descritas.

\section{Olhares sobre a representação do jornalista: procedimentos metodológicos}

Para a tarefa de análise da "representação" do jornalista nas duas produções que nos servem de recorte, utilizaremos, como metodologia-chave, a análise textual da televisão, proposta por Francesco Casetti e Federico di Chio na obra "Análisis de la televisión" (1997). Esta perspectiva toma como parâmetro ferramentas da análise de discurso e de conteúdo, embora não se limite às duas tradicionais metodologias.

Casetti e Chio justificam as razões para a elaboração de sua obra/proposta analítica pelo fato de que a televisão, embora constitua o centro de diversas pesquisas, continua sendo um objeto de investigação complexo e furtivo. Complexo por suas inúmeras faces: dispositivo tecnológico, produtor de informação e de espetáculo, instrumento ideológico, dentre muitas outras. Já a categorização da televisão em furtiva, ou elusiva como preferem os autores, deve-se aos seus diferentes "modos de ser que se sucedem e se substituem em função de diferentes tempos e lugares" (1997, p.14). Têmse, assim, "as televisões" generalistas, temáticas, a cabo, prestadoras de serviço público, puramente comerciais. Nossa proposta concentra-se em "encarar" a TV em sua face 
enquanto meio de comunicação, com foco nos efeitos sociais e nas representações que produz, em caráter generalista e entendida como prestadora de serviço público, embora seu caráter comercial não seja fator isolado a se desprezar.

Casseti e Chio argumentam que "o estilo de comportamento dos sujeitos" (1997, p.252) dá pistas sobre a representação do/para o público que se pretende ofertar via TV, principalmente por sua interação com os outros personagens. Deixamos clara a concepção de representação adotada em nossa pesquisa, tributária dos estudos culturais e elucidada por Simone Rocha (2008). A pesquisadora retoma Raymond Willians (1976, p.269) para distinguir dois sentidos da palavra "representação". No mundo da arte é sinônimo de "reprodução acurada". Interessa-nos a segunda definição, mais recente, que significa, grosso modo, "como a realidade é apresentada nos estudos culturais e nos estúdios de media”. (ROCHA, 2008, p. 88). Para Stuart Hall, sob ângulo construtivista, a representação pode ser entendida, de modo semelhante, a um "mapa conceitual" (1997), ou seja, uma construção social onde as pessoas só se comunicam de forma significativa se compartilharem um mapa similar.

Não existe, neste contexto, um significado inerente às coisas, mas sim aquele construído e produzido como resultado de uma prática significativa, que faz as coisas adquirirem sentido. Stuart Hall reconhece o caráter público e sociocultural da representação, seu caráter construcionista e anti-essencialista. A discussão é fundamental para entendermos como as identidades se inscrevem nessa dinâmica interacional estabelecida via jornalismo de TV.

Já percebemos, com base em pesquisas anteriores, que os VT's são palco privilegiado de "atuação" destes personagens, dentre os quais o povo e os jornalistas/repórteres se encontram inseridos e com "lugares de fala" demarcados. A análise textual da TV permite uma abordagem qualitativamente mais aprofundada sobre a questão, em consonância com o aporte teórico utilizado. As representações delineadas na análise textual da TV, passam a ser avaliadas nos efeitos de sentido globais que produzem. Desse modo, não se trata apenas de medir quantitativamente a presença de 
determinados temas, figuras ou ambientes, mas colocar em relevo a arquitetura e funcionamento dos programas analisados, bem como a disposição de vítimas, mocinhos, vilões, arautos e outros personagens em cena.

Nossa análise priorizou, nos dois vídeos observados e seus personagens apontados (com foco no papel do jornalista nestas narrativas), esquemas de leitura baseados em um eixo principal proposto por Casseti e Chio: Sujeitos e Interações. Destacaremos aqui a disposição dos "jornalistas-personagens" que integram os vídeos. O estilo de comportamento dos mesmos e a função de cada sujeito no desenvolvimento da narrativa serão priorizados. Sendo assim, a categoria narrativa do "personagem", um dos componentes da dramaturgia do telejornalismo (COUTINHO, 2003) e sua interação em cena orientou todo o processo de interpretação, descrito a seguir.

\section{Arauto ou fiscal? As representações do jornalista-testemunha}

$\mathrm{O}$ arauto (do francês antigo: heralt) pode ser compreendido como o mensageiro oficial na Idade Média, uma pré-forma do diplomata. $\mathrm{O}$ arauto fazia as proclamações solenes, verificava títulos de nobreza, transmitia mensagens, anunciava a guerra e proclamava a paz. Na monarquia moderna, o arauto passa a apregoar casamentos reais ou aclamações dos reis.

Na tradição católica, Lúcia é categorizada como arauto de Nossa Senhora de Fátima. No dia 13 de Maio de 1917, três crianças - Lúcia de Jesus dos Santos (10 anos), e seus primos, os irmãos Francisco Marto (9 anos) e Jacinta Marto (7 anos) afirmaram ter visto "...uma senhora mais branca que o Sol" sobre uma azinheira de um metro ou pouco mais de altura, quando cuidavam de um pequeno rebanho na Cova da Iria, freguesia de Aljustrel, pertencente à Vila Nova de Ourém, Portugal. As aparições repetiram-se nos cinco meses seguintes e seriam portadoras de uma mensagem ao mundo. A 13 de Outubro de 1917 a aparição disse-lhes ser a Nossa Senhora do Rosário de Fátima. 
No relato católico, Lúcia via, ouvia e falava com a aparição, Jacinta via e ouvia e Francisco apenas via, mas não a ouvia. Lúcia tinha, portanto, sua função de arauto potencializada em relação às outras duas crianças, pela própria amplitude de seus sentidos. Fugindo das amarras e polêmicas que envolvem a crença ou descrédito nas aparições - que não nos interessam no âmbito deste trabalho - é importante perceber como as mortes de Francisco, em 1919, e de Jacinta, no ano seguinte - quando ainda eram crianças - colocam Lúcia no papel de contadora oficial da história até sua morte, em 2005. Os relatos destes acontecimentos, bem como os três segredos ${ }^{2}$ ou mistérios de Fátima - revelados aos capítulos ao longo de seis décadas, foram redigidos pela então Irmã Lúcia a partir de 1935, em quatro manuscritos, habitualmente designados por Memórias I, II, III e IV. Deve-se à Lúcia, "mulher de carne e osso" portanto a celebração, o protagonismo no relato dos fatos e a manutenção da narrativa "ofertada" por Nossa Senhora de Fátima.

Em contexto contemporâneo, Joseph Kizerbo, citado em trabalho de Stuart Hall, estuda a função do arauto como mantenedor das culturas africanas na atualidade. Kizerbo entenderá que a questão do arauto, a sua figura e simbologia estão inseridas numa "posição de destaque, pois lhe cabia transmitir a tradição histórica: era o cronista, o genealogista, aquele que dominava a palavra, o anúncio das coisas." (KIZERBO, 1982, apud HALL, 1997, p. 77). Nessa perspectiva, o autor analisa romances que ressaltam o papel do arauto enquanto mantenedor da cultura oral africana. $\mathrm{O}$ romance Ponciá Vicêncio parece-nos inserir-se nesse contexto. Com temática afro, o narrador nos brinda com personagens que cumprem esse papel na narrativa, como é o caso de Nêngua Kainda, sem a qual o enredo não se desenrola e não avança.

Nessa percepção, a figura do arauto pode ser entendida como função socializadora, de anunciação e proclamação. Torna-se tradutora de uma cultura, de uma identidade e anunciadora das mesmas - função que muito se relaciona com esta

2 Os segredos eram constituídos por três partes, de carácter profético e interpretados simbolicamente: a visão do inferno (1), a conversão da Rússia (2) e a luta dos ateus contra a igreja (3). As duas primeiras partes foram reveladas em 1941, num documento escrito por Lúcia. A terceira parte foi escrita por Lúcia em 3 de Janeiro de 1944, por ordem do bispo de Leiria, e revelada em 2000. 
representada pelos telejornalistas aqui analisados.

Seja no caso arquetípico do arauto da Idade Média, no papel de Lúcia como portadora privilegiada de segredos, ou no de Nêngua Kainda para manter a cultura afro, a função desse "personagem" emergiu em nossa análise de maneira sistêmica e frequente, exigindo-nos sua incorporação em nossos esquemas de dramaturgia do telejornalismo. Repórteres, cinegrafistas e âncoras colocam-se na posição de proclamadores de boas (ou não tão boas) novas - como é o caso das tragédias no Morro do Bumba e na Região serrana do Rio - e as ofertam/negociam com seu público ao longo de cada matéria que "anunciam". Nesses casos, a função de jornalista como físcal ou mediador de determinada sociedade cede espaço para seu papel enquanto mantenedor da tessitura da trama. Ele passa a ser - ou ao menos presume isso - um indivíduo aceito e autorizado pela comunidade ou audiência para coordenar e realizar a anunciação, contar a história. É aquele que, na narrativa, mais vê, ouve e fala.

É ainda o arauto que, na maioria das vezes, irá nos apresentar as funções dos outros personagens no desfecho da narrativa telejornalística: as razões que levaram a vítima a se sentir como tal, o contexto responsável pela criação do vilão, a descrição do cenário onde se passa a trama, e, sobretudo, apresentar os beneficiados, heróis, mocinhos e troféus, em matérias de celebração.

O estudo da relação entre os personagens classificados como fiscais e arautos nos dá pistas sobre o direcionamento do telejornal em relação a seu público, as promessas discursivas que tentam estabelecer. Isto porque temos que, no caso de nosso recorte, esses dois papéis são desempenhados quase que totalmente por repórteres e âncoras. E demonstram a maneira com que estes e o próprio telejornal se projetam para o público que tentam representar e também para as outras fontes presentes na narrativaVT. Numa postura mais incisiva, o fiscal cobra providências das autoridades-vilãs que surgem nas matérias, engrossa o coro da população ao pedir o restabelecimento da ordem, tenta gerar identificação com o público na reclamação pelos serviços reguladores prestados. 
Nosso olhar se volta de maneira particular para arautos e fiscais neste percurso. Primeiramente, são personagens que poderiam passar despercebidos, dependendo do enfoque que assumíssemos, por não representarem os personagens preferenciais de nossos estudos, o povo que assiste ao telejornal, e que é representado por ele nos papéis de vítima, mocinhos, beneficiados, etc. Esse tipo de invisibilidade quanto ao seu lugar na narrativa audiovisual não deve acontecer, uma vez que cumpre atentar para o fato de que são eles que introduzem as outras histórias e personagens. Além disso, uma de suas funções de destaque é a de interpelar, com maior ou menor frequência dependendo do telejornal, o cidadão que se encontra do outro lado da TV. É o que observaremos adiante, ao analisar os depoimentos das jornalistas Sônia Bridi e Fátima Bernardes, quando abordam, respectivamente, as coberturas das tragédias climáticas ${ }^{3}$ no Morro do Bumba (2010) e na região serrana do Rio de Janeiro (2011).

\section{A (e)nunciação da tragédia}

Ao relatar os bastidores da tragédia na região serrana do Rio para o Canal F (seção do site do Fantástico na web, que se intitula "nosso programa diário na internet", espécie de extensão virtualizada da versão semanal da revista eletrônica televisiva), a repórter Sônia Bridi anuncia, de antemão, o envolvimento "emocional" a que se sujeitara ao se tornar testemunha, "arauto" dos acontecimentos. Reconhece as limitações da cobertura audiovisual, ao explicitar, em sua "colocação em cena" que "a gente não consegue, mesmo com todo este imenso esforço, mostrar a tragédia em toda a sua dimensão. Tem coisas que simplesmente não cabem no áudio e no vídeo de uma televisão" (BRIDI, 2012). Os depoimentos das fontes, sejam elas autoridades, experts ou testemunhos são determinantes na construção do acontecimento. Afinal, conforme aponta Márcia Franz Amaral (2011):

3 A ANDI (Associação Nacional dos Direitos da Infância) realizou a pesquisa Mudanças Climáticas na Imprensa Brasileira que analisou 50 jornais brasileiros entre 2005 e 2007. Com base na pesquisa, Fioravanti (2010) afirma que a nova vedete do jornalismo é a mudança climática. No jornal Folha de S.Paulo, por exemplo, a quantidade de reportagens cresceu quatro vezes entre 2006 e 2007. 
o acontecimento não é uma realidade objetiva externa alheia ao sujeito que a percebe (ALSINA, 2009, p.12). A escolha e a manifestação das fontes estão condicionadas ao tipo de acontecimento em questão e ajudam a construí-lo. $\mathrm{O}$ acontecimento catastrófico demanda várias fontes para reconstituir os elementos do passado e do presente. As fontes auxiliam no cumprimento do contrato pragmático e fiduciário com o leitor na exigência de que a informação midiática seja real. E os testemunhos costumam ter visibilidade nas catástrofes porque possuem esta especificidade.(...) os testemunhos têm visibilidade pelo relato da sua experiência, pois presenciaram o fato, participaram diretamente da sua causa ou sofreram as consequências dele.

Crucial perceber que a jornalista, ao se "envolver" com a catástrofe que relata e reconhecer tal envolvimento - conforme é possível ver/ouvir em diversas de suas falas, acaba se despindo de sua função "oficial” na narrativa e se torna fonte, juntamente com a população "imersa” na catástrofe. A jornalista Fátima Bernardes assume postura parecida, ao falar sobre sua participação na cobertura da tragédia no Morro do Bumba, em Niterói. A então apresentadora do Jornal Nacional mescla o anúncio dos fatos com certa postura testemunhal, espécie de compartilhamento da dor coletiva diante da situação. A entrevista com o editor do site do Jornal Nacional, Alfredo Bokel, tem duração de oito minutos e 46 segundos ( $\left.8^{\prime} 46^{\prime \prime}\right)$, durante os quais há inserções de imagens da cobertura e perguntas sobre o caráter diferenciado daquele trabalho.

$\mathrm{O}$ aspecto místico também está presente na narrativa, em diferentes momentos. Ao falar da escolha pelo local para o qual se deslocaria a equipe do Jornal Nacional, Fátima lembra que a opção seria pelo local que estivesse sendo mais atingido. Os deslizamentos ocorridos no Morro do Bumba, em Niterói, são assim enunciados pela jornalista como uma espécie de sinal de que era pra lá que os profissionais do $J N$ teriam que ir. Na pergunta do colega de trabalho sobre a reação de Fátima nesse tipo de cobertura com "tantos anos de experiência" chama a atenção o termo ainda como contraponto associado a reações como ansiedade e nervosismo. Dessa forma está presente o marcador normativo de que os repórteres deveriam manter suas emoções sob controle. A resposta de Fátima contudo sinaliza em direção contrária a esse modelo, mas 
sim em uma possível rota de aproximação com o telespectador, com o público.

É uma cobertura muito mais tensa. Primeiro, porque você está lidando com a emoção de todo mundo e com a sua própria, porque é impossível chegar a um lugar como esse e não se envolver. Segundo porque é muito difícil você chegar para aquelas pessoas que estão tão sofridas e ainda esperar que olhem para você e te respondam alguma coisa, que tenham essa compreensão. Então é um pedido de desculpas que eu faço sempre, porque é óbvio que eu não gostaria de estar naquela situação. Mas faz parte do meu trabalho (BERNARDES, 2010).

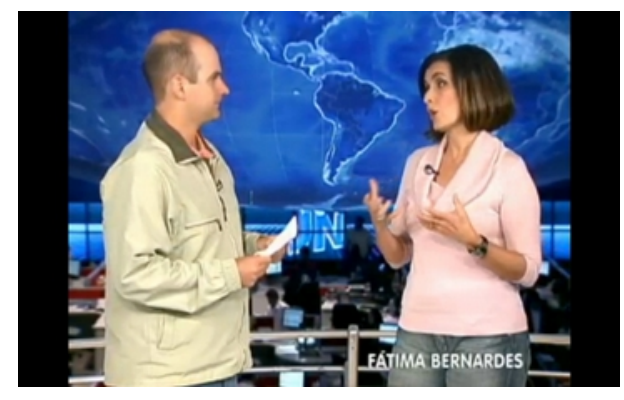

Outro aspecto que merece destaque na narrativa da jornalista é sua enunciação do que poderia ser entendido como uma carência de espaço para o exercício de direito à comunicação pelos cidadãos. Então editora e apresentadora do telejornal mais longevo e assistido da televisão brasileira, Fátima Bernardes não relaciona essa demanda ao campo da mídia contudo, mas destaca a não existência de acesso aos direitos mais gerais, cuja oferta e vigilância caberia ao Estado. Segundo ela os moradores das regiões atingidas e seu entorno, em um momento crítico, perceberiam que nessa hora teriam chance de ter voz, e se aproximariam para falar "de como eles estão sendo negligenciados (...) as pessoas estão muito ávidas por contar a história delas e de alguma forma serem ouvidas" (BERNARDES, 2010). Qualquer semelhança com a proposta do programa Encontro com Fátima Bernardes, apresentado pela jornalista desde 2012, poderia talvez não ser considerada mera coincidência, assim como sua história com uma das entrevistadas naquela cobertura, a menina Laura Beatriz, de apenas oito anos.

A jornalista descreve a dor generalizada como o aspecto mais marcante da 
cobertura da tragédia, assim como seu encontro com uma entrevistada cujo caminho teria se cruzado com o dela. Fátima descreve o momento em que uma criança, que ela sabia ser a única sobrevivente do deslizamento de uma casa, teve uma crise de choro, e abraçou um adulto: "Perguntei o nome e a pessoa falou: Laura Beatriz. Aí quem quase caiu fui eu...Depois eu falei pra ela que eu tinha duas filhas, que se chamavam Laura e Beatriz e eram gêmeas; e ela deu um sorriso..." (BERNARDES, 2010). Essa informação é amplamente conhecida, tendo sido objeto de análise de pesquisadores como Sean Hagen (2008) e Gilze Bara (2012) sobre as estratégias de aproximação do $J N$ com o público, por meio de seus apresentadores.

Além disso a questão da humanização do relato, também via repórter aparece a nosso ver como numa espécie de "prisma discursivo", onde o papel testemunhal desempenhado pelos profissionais oferta diversas possibilidades de representação. Fica evidente nos trechos das duas entrevistas, que, se por um lado, as profissionais assumem postura de "fragilidade e sensibilidade compartilhada" - que se aclimata ao discurso de indignação e espanto da população, por outro percebemos a publicização de valores ligados aos direitos humanos, que são seguidamente a base imaginária da cobertura midiática dos acidentes - e por que não dizer - diretrizes de uma suposta "conduta jornalística" geral, assumida pela emissora e explicitada nas diretrizes editoriais das Organizações Globo.

Para Amaral (2011), o relato jornalístico tem em si, muitas vezes, um tom testemunhal, por intermédio do que Laurindo (2008) denomina autor-jornalista. O autorjornalista é aquele que exerce a função autoral na dimensão mais adequada à epistemologia do jornalismo como expressão do conhecimento através da experiência mediada e não da experiência em si. Entretanto, em casos de tragédias, a situação é tão dramática, que presenciar os momentos pós-tragédia é suficiente para ser testemunha do acontecimento traumático. Tenta-se dessa forma, apresentar ao público um repórter que transcende a autoria da experiência mediada, inserindo-se diretamente na situação traumática. 
É essa situação que nos mostra outro trecho, este veiculado na cobertura das chuvas na região serrana, que destacamos em nossa análise. Nele, a repórter Sônia Bridi coloca-se na rotina de mazelas vivida pelos moradores da região serrana. Ao longo de cinco minutos e 54 segundos de material em vídeo disponível na web a repórter com experiência como correspondente internacional e autora de livros como Laowai também sofre com a interdição dos acessos nos "caminhos bloqueados pela terra", avança pelo lodaçal, acompanha a população, chega a locais nos quais nem os bombeiros tiveram acesso ainda. E solidariza-se com o sofrimento de uma idosa ferida em desabamento, a quem chama de "vó".

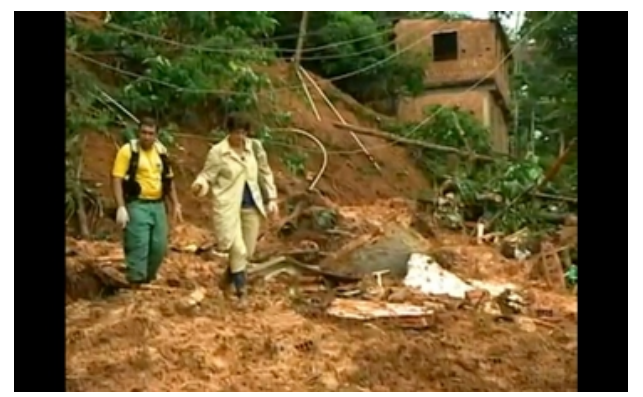

No auge do envolvimento com a população atingida pelo desastre natural, liga para a filha de uma moradora, depois de ouvir o apelo de sua mãe, que, no meio do caos instaurado, recosta chorando no ombro da jornalista, implorando-a que "Fale que a gente não morreu, que a gente está bem, por favor". As preocupações da repórter extrapolam, neste e em outros pontos, aspectos relacionados apenas com a apuração/ narrativa da informação ou com a construção da matéria. 


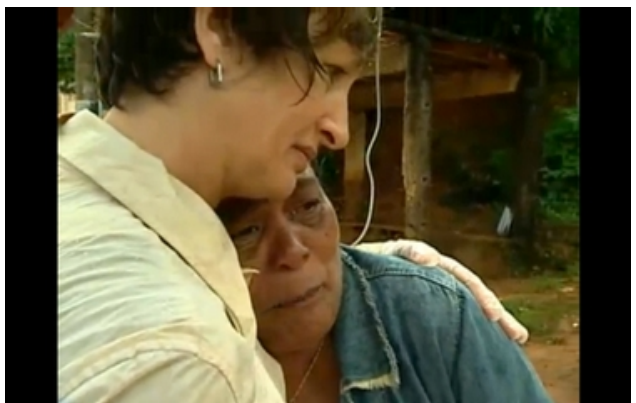

A imagem do abraço entre vítima-popular e jornalista-vítima soa como emblemática da representação de compartilhamento da dor, bem como do testemunho da mesma. Despida discursivamente da função de jornalista, "apenas", Bridi se coloca na condição de cidadã-comum e passa a procurar um local com sinal de celular, para realizar a ligação que lhe fora pedida. Amaral observa em seu trabalho que posturas como a da repórter são frequentes em boletins ao vivo ou em textos autorais de reportagem, como esse tomado como objeto de análise, quando "o repórter, mesmo não sendo vítima, nem tendo experienciado diretamente a situação traumática, assume este lugar por chegar no calor do acontecimentos".

Em trecho seguinte, Sônia Bridi reafirma seu compromisso extraprofissional assumido, relatado num misto de angústia e felicidade estampada no rosto: "O chão se abrindo ao longo de toda a estrada. Percebo que há sinal de celular e cumpro a promessa feita lá no alto - Roberta, a sua mãe pediu para ligar avisando que ela está bem! (o nervosismo e o alívio podem ser sentidos do outro lado da linha) - Ela só pediu para eu te tranquilizar, tá?".

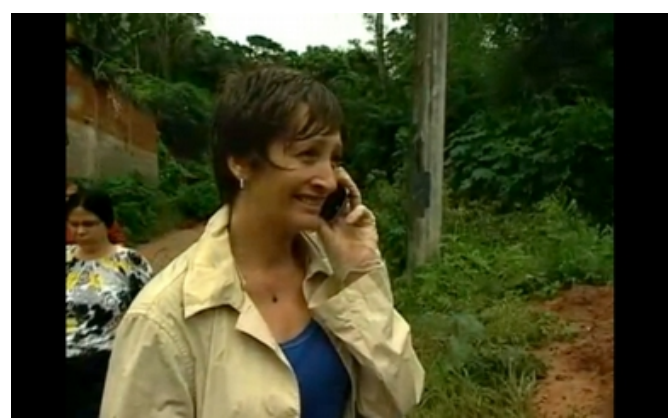


Márcia Franz Amaral, a partir de Izard e Pekins (2005), argumenta que as coberturas de tragédia abrem precedente para que os repórteres não realizem um trabalho de cobertura supostamente "equilibrado", levando-se em conta os que Bucci considera como cânones anacrônicos do jornalismo. Apesar disso, ainda que mais afetados pelos aspectos emocionais, ou pelo maior envolvimento com as fontes devem buscar a verdade, comparar e contrastar os diversos pontos de vista para melhor representar a realidade. Nestes casos entendemos que uma cobertura "equilibrada" ou balanceada privilegiaria o status quo, quando o trabalho mais diferenciado deveria se focar num mosaico em que se inserem o testemunho e descrição do acontecimento, além também de doses fartas de engajamento.

A eventual parcialidade não é dessa forma considerada uma "tomada de posição", mas, acima de tudo apresenta-se como fragmento do olhar daquele que diz sobre o ocorrido. Essa seria outra característica do tom testemunhal presente na "colocação em cena" da repórter. E se, "seu objetivo primeiro não é reconstruir a história, mas relatá-la de seu ponto de vista individual" (AMARAL, 2012), quanto menos imparcial for o testemunho, mais envolvente será. Sônia Bridi se projeta no fragmento da matéria, reeditado em sua entrevista ao Canal $F$, como arauto de uma (improvável) boa nova, anunciando a uma filha que as coisas vão bem - na medida do possível - com sua mãe.

Ainda em busca de uma possível conclusão, vale observar em que medida a participação de repórteres experientes das emissoras de televisão como narradoras de componentes emocionais pode ser compreendida como um elemento constituinte da narrativa midiática desse tipo de cobertura, de desastres e tragédias. Omar Rincón (2006), ao abordar esse tipo de construção audiovisual no que considera a sociedade do entretenimento coloca em relevo alguns critérios valorativos por meio dos quais seria possível estabelecer quatro juízos de valor estético: de natureza emotiva, de valor subjetivo, de gosto e de validade coletiva.

Dois desses juízos parecem estar presentes nas narrativas de Fátima Bernardes e 
Sônia Bridi, e parecem ajudar a compreender melhor o papel do repórter nesse tipo de cobertura televisiva: o juízo de natureza emotiva e o juízo de validade coletiva. $\mathrm{O}$ primeiro, construído entre o prazer e a dor, seria obtido a partir da apreciação dos sujeitos em cena, repórteres e entrevistados que atuariam no cenário descortinado pelo telejornal. Nesse caso o principal componente da narrativa seria a emoção, para além dos aspectos cognitivos.

Como forma de contraponto a uma frequente acusação de sensacionalismo, por meio do privilégio à emoção, entraria em cena o juízo de validade coletiva, que busca as generalizações. Esse tipo de recurso fala da necessidade da narrativa televisiva ser aprovada e legitimada, sobretudo pelo público. A emoção, o caráter excepcional não pode ser solitário, individual, quando perderia seus referentes. Por isso os relatos emocionais, mobilizando referências quase universais, como a repórter-mãe, a preocupação com os filhos, oferecem ou ao menos simulam uma proposta de encontro, com o telespectador e público, ainda que pelo consumo de jornalismo audiovisual fora da televisão. 


\section{Referências Bibliográficas}

AMARAL, Márcia Franz. Os testemunhos na cobertura das catástrofes ambientais. Anais do XX Encontro Anual da Compós. UFRGS: Porto Alegre, 2011. Cdrom.

BERNARDES, Fátima. Entrevista concedida a Alfredo Borkel em 12/04/2010. Disponível em: http://g1.globo.com/jornal-nacional/videos/t/edicoes/v/jn-especial-fatima-bernardes-fala-sobre-acobertura-das-chuvas-em-niteroi/1246267/ Acesso: 17/08/2012.

BONNER, William. Jornal Nacional - Modo de Fazer. Rio de Janeiro: Globo, 2009.

BUCCI, Eugênio. Na TV, os cânones do jornalismo são anacrônicos. Seminário Internacional Ética e Cultura. Disponível em: http://www.sescsp.org.br/sesc/conferencias/subindex.cfm ? Referencia=146\&ID=105\&ParamEnd=9 . Acesso: 18/08/2012.

CANAL F, Fantástico. Sônia Bridi relata bastidores da tragédia no Rio e faz apelo: "Quem puder, ajude". Disponível em http://fantastico.globo.com/Jornalismo/FANT/0, MUL1642161-15605,00.html Acesso: 16/08/2012.

CASETTI, Francesco e CHIO, Federico di. Analisis de la Televisión - Instrumentos, Métodos y Prácticas de Investigación. Barcelona: Paidós, 1998.

COUTINHO, Iluska. Dramaturgia do telejornalismo brasileiro. São Bernardo do Campo: Umesp, 2003. Tese de doutorado.

GLOBO.COM. Jornal Nacional vence o International Emmy Awards 2011 em 'Notícia'. Disponível em http://redeglobo.globo.com/novidades/noticia/2011/09/jornal-nacional-vence-o-international-emmyawards-2011-em-noticia.html Acesso: 20/08/2012.

HALL, Stuart. Da diáspora: Identidades e mediações culturais. Org. Liv Sovik. Trad. Adelaine la Guardia Resende et al. Belo Horizonte: Ed. UFMG, 2003, 434 p.

JESUS, Irmã Maria Lúcia de. Memórias. 13a edição, Secretariado dos Pastorinhos, Outubro de 2007.

KI-ZERBO, Joseph. História Geral da África: metodologia e pré-História da África. vol. I. São Paulo, Ática; Paris, Unesco, 1982.

RINCÓN, Omar. Narrativas mediáticas. Barcelona: Gedisa, 2006.

ROCHA, Simone Maria. Estudos culturais e estúdios de mídia: modos de apresentação do sujeito em programas televisivos, 2008. p. 87-98. Revista Libero (online). Ano XI, n. 21, Julho 2008. Disponível em http://revcom.portcom.intercom.org.br/index.php/libero/article/viewFile/5418/4937

WHITE, Ted. Jornalismo eletrônico: redação, reportagem e produção. 4a. Ed. São Paulo: Roca, 2008.

Este artigo e todo o conteúdo da Estudos em Jornalismo e Mídia estão disponíveis em http://www.periodicos.ufsc.br/index.php/jornalismo/index

Estudos em Jornalismo e Mídia está sob a Licença Creative Commons 